\title{
Dynamics of Regional Fisheries Organization's and Foreign Trade: Emphasis on the Environment and Restructuring in Mexico
}

\author{
Hidalgo Gallardo Amada, Hidalgo Gallardo Ruth Leticia, Ávila Hidalgo Sofía Elizabeth \\ Department of Economic and Management Science, University of Hidalgo State, Pachuca, México \\ Email: misshidalgo2009@yahoo.com.mx, ruth.757@hotmail.com, avila_soeli@hotmail.com
}

How to cite this paper: Amada, H.G., Leticia, H.G.R. and Elizabeth, Á.H.S. (2017) Dynamics of Regional Fisheries Organization's and Foreign Trade: Emphasis on the Environment and Restructuring in Mexico. Journal of Human Resource and Sustainability Studies, 5, 1-11.

https://doi.org/10.4236/jhrss.2017.51001

Received: January 24, 2017

Accepted: February 12, 2017

Published: February 15, 2017

Copyright $\odot 2017$ by authors and Scientific Research Publishing Inc. This work is licensed under the Creative Commons Attribution International License (CC BY 4.0).

http://creativecommons.org/licenses/by/4.0/

\begin{abstract}
This article has the purpose to give a perspective related with actions about climate change, fishing, fisheries regional organizations and the States regarding trading sector, considering that fishing is a vulnerable but important sector for food security. However, it is important to analyze the applications of external politics in internal national politics about restructuring fishing, safeguard and respect the resource natural. According to the theme, this study has been suitable to analyze it from the theories of the interdependence complex (Keohane and Nye, 1977 [1]), and vulnerability and sensitivity theories (Katzenstein, 1976 [2], Dhal, 1957 [3], Tucker, 1977 [4] and Holsti, 2006 [5]) in the application of external policies, and make the most vulnerable States as well as the sensitivity in their sectors. In order to verify the implementation of all policies also to prove the climate change governance, it has been determined to analyze the case of Mexico (2006-2013) who is facing this phenomenon. The results show that while Mexico has implemented programs and projects, the achievements will be given in a long term, due to the lack of infrastructure, technology, innovation and technical capacity. The strategies of Mexico government go through links with the Regional Fisheries Organization in order to achieve the best strategies for maintaining fishery productivity and trade sector.
\end{abstract}

\section{Keywords}

Environmental Regulation, Foreign Trade, Regional Fisheries Management Organizations (RFMOs), Fishing, Mexico

\section{Introduction}

Today the International Community (IC) is addressing challenges such as: economic interdependence, natural resources and environment. These challenges 
concern to humanity who looks how to ensure the ecosystem, food and life.

Environmental pollution in the seas has confronted the States and International Organizations (IGOs) to discuss and process the strategies which are necessary for its containment. This international scene, the most catastrophic of recent times, is making rapid changes related to markets, exploitation and forms of governance in fisheries.

So, on one hand there is the vulnerability in fishing activity, and on the other the sensitivity in states to abide by the international policies on restructuring and resource, which generally affects to the less developed countries that at the same time present overfishing. Here that States adhere to the determinations of International Organizations (IGOs) with the purpose to provide mechanism and support to safeguard this economic activity, without affecting production or foreign trade sector.

The International Community (IC) proposal on it goes regarding the Regional Fisheries Management Organizations (RFMOs) who are responsible for providing information to States about the dynamics of regional and global fisheries. The aim is that with this information States may take decisions on their strategies of exploitation, domestic consumption and trading expectations. In Mexico, the fishing activity is important because of its geographic location but is also highly susceptible of climate events; before these two aspects the support of the RFMOs for Mexico is essential because it can generate mechanisms of protection, at same time of be assertive in taking decisions.

In this context, International Community (IC) tends to search strategies to face the shortage of fisheries, displayed to next generations but it is clear that currently the demand of fish is intensified, prices tend to increase, production diminishes and fishing activity is each time more globalized.

\section{Methodology}

This investigation is orientated to the application of the descriptive analytical method and substantiated on the Complex Interdependence Theory of [1], both recognize that economic acceleration have contribute to the global warming phenomenon who has taken to unexpected consequences in all aspects. This situation exposes States to look for methods to address this global overview. Furthermore the opinions of [2] [3] [4] [5] are taking into account regard to the conditions of sensibility and vulnerability that States address derived from the foreign policies applicable on their domestic policies. This case of study verifies Mexico's sensibility owing to the fishing restructuration through international system; also it is interpreted fishing vulnerability, transformation, threat and habitat change which are derived from the environmental phenomenon.

On this basis, is resorted to the recompilation and analysis of data and information from documents and literature surveys from the Regional's Fisheries Management Organizations (RFMOs) as well as the guidelines of specific organizations for environmental treatment and their consequences on fishing trade. This analysis specifies the implemented actions by Mexico on their domestic 
policies between 2006-2013 with the purpose of counteracting the international rate with national application. Documents such as the Development National Plan, the Official Journal of the Federation and National Regulation are considered.

Furthermore, documents, strategies, reports and data of Mexican government agencies are reviewed for the frame of reference to present a complete analysis; transcendental for the phenomenon of study.

\subsection{Regional Fisheries Management Organizations (RFMOs) as the Way for Industry Restructuring}

In accordance with Sarukhán, et al., (2009) [6] the international approach; Mexico is a mega diverse country, since it has between 60 and $70 \%$ of the planet diversity, taking into account privileged geographic location (11,592 $\mathrm{km}$ of shore, 3 million $\mathrm{km}^{2}$ of Exclusive Economic Zone (EEZ), 2.9 million of continental water has) which contains many ecosystems and species with the most varied forms of life but SEMARNAT (2007) [7] has mentioned that the future with the changing climate affects in increase of the level of the sea with impacts to the ecosystem coastal and marine; according with the OECD regarding its situation, the Mexican fishing activity is important for national and international economy. The Mexican government has a long term view to encourage national development, competitiveness and fishing strategic planning, articulated on the (PND) Development National Plan (OECD, 2013) [8].

The international policies on fishing restructuring focus on the RFMOs as an essential part on the guideline ruling. It is relevant to connect the RFMOs since it arises from international agreements where States decide to bring them the management of natural resource from a determined area. Therefore, these are mechanisms created to provide statistic and analytical data information with the aim of help both, governments and Intergovernmental Organizations, to make pertinent decisions about the responsible use of resources towards conservation, management and development of fishing resources ${ }^{1}$.

Similarly there are other organisms dedicated on coordination and cooperation as Regional Organizations of Fishing Management (OROP) who then, have implemented on their faculties and procedures the application of international legal instruments. Such instruments ought to exercise efficiency in the resources' conservation and order ensuring sustainability ${ }^{2}$.

In this approach, it is denoted the recapitalization of the industry which is amplified and transformed with the aim to answer the problematic of the activity. One more time it is confirmed that the variables to balance such as: overexploitation, capitalization, technology, fleet renewal, subsidies, competence between manufacturing and artisanal fishing are multidimensional and hard to harmonize (Fernández, 2006) [9].

${ }^{1}$ The Royal Institute of International Affair. Buenas prácticas recomendadas para las OROP 2007. ${ }^{2}$ Comisión Permanente del Pacífico Sur.-Ordenamiento Jurídico Internacional de la Pesca 2009. http://www.pnuma.org/gobernanza/cd/Conferencias/3\%20Jueves\%207/Ordenamiento\%20Jur\%EDd ico\%20de\%20la\%20Pesca\%20en\%20Alta\%20Mar..pdf 
Given this scenario, Mexico joins into the international arrangements as Law of the Seas and Responsible Fishing, regulations which are the guide for the IC to make the appropriate considerations on their governments to safeguard the environment and the natural resource. Mexico is part of this commitment at the time on signing multilateral conventions such as, UNCLOS in 1982, FAO in 1995 and COFI. Additionally, Mexico belongs and contribute with global and interoceanic RFMOs as the International Whaling Commission (IWC), and the Latin-American Organization for Fishing Development (OLDEPESCA) ${ }^{3}$.

In the Atlantic, Mexico participates in the International Commission for the Conservation of Atlantic Tunas (ICCAT) and the Western Central Atlantic Fishery Commission (WCAFC). In the pacific, the country is member of the Inter-American Tropical Tuna Commission (IATTC) and regard to the fishing on inland waters; it belongs to the Aquaculture and Fishing Commission of Latin America and the Caribbean (COPESCAAL). Therefore, for Mexico the collaboration with RFMOs offers a panoramic to consider in the future.

It is regarded that fishing represents today's major threatening for open sea, but another potentially dangerous activities-such as: biosprection, mining, energetic production and $\mathrm{CO}_{2}$ retention-could constitute future threats for marine biodiversity that would make necessary the instauration of a complex set of management agreements.

Therefore, the impact of Climate Change will confront regard to the industry trends and the situations presented on fishing activity, thus, International Community has reaffirm the decisive importance of RFMOs and the need to strength and modernize them ${ }^{4}$.

\subsection{The Environmental Influence on Mexican Fishing}

The fishing industry is facing dramatic consequences derived of various circumstances such as; climate change, pollution and acidification of seas, infrastructure and net fishing. These aspects have contributed to fishing sensibility and on their uncertain future regard on climate variability. The same fishing industry contributes on greenhouse effect derived from their activities on capture, transport, elaboration and storage. Considering that fishing ships consume and throw fuel into the sea, and also that in many cases, fishing periods are long.

Consequently, actually it has increase health deterioration of aquatic ecosystems on seaside areas, this area is objective of an excessive exploitation or an excessive waste feeds. As seaside ecosystems are essentials for reproduction and growth of numerous marine species, the impact of degradation over the volume of marine resources including those of commercial importance is direct and negative ${ }^{5}$.

In the case of Mexico, the government on the National Development Plan (PND) 2006-2012, confirms that fishing managements on Climate Change Spe- 
cial Program (PECC)includes variations on climate factors, for that reason, the adaptive capacity of the fisheries of the country is strengthened. Within the timeframe 2009-2012, it has been elaborated that more than $60 \%$ of fishing programs considered on the objectives, being in process the totality of the committed programs.

The National Charter for Fisheries (CNP) determines that from 75 fishing handling units, 45 (60\%) have reached their maximum capacity, being complete exploited 20 (26.6\%) record overexploitation of $86.6 \%$ from fishing marine units. This means that they are no more susceptible to an increase of production. On the contrary, many of them require management and protection actions to stop deterioration. National Commission for Aquaculture and Fisheries CONAPESCA attests to the above estimating that only $14.2 \%$ of fisheries have potential development [6].

Mexico faces a considerable environmental pressure; the estimations indicate that the $68 \%$ of population and the $71 \%$ of GDP are very exposed to climate change risks. This situation affects agriculture production, water availability, deforestation, biodiversity and health. Even if does not exist attributable alterations on climate change, it is generally estimated that it is necessary to reduce the fishing capacity and effort on most of the fisheries (Daw, et al., 2009) [10]. Nevertheless, the reduction of greenhouse effects is still an important challenge since, if they continue increasing, natural catastrophes will heat coastlines and consequently the productivity of marine natural resource [8].

Mexico bases their fishing strength on their vast coastlines but, due to its geographic location, is facing natural phenomena as "El Niño" which generates changes in the position of pelagic fisheries, higher losses due to bad weather and risks for fishermen because of population migration and the obtaining of the resource. In any case, procedures of fisheries governance have to be malleable to changes and oriented to equal and sustainable fishing and on an eco-systemic approach with can increase the capacity of fishing adaptation [10].

\subsection{Production and Marketing of Mexican Fishing before RFMOs Restructuring, Environmental and Guideline Measurements}

The Mexican government adjusts their domestic and management policies in order to restructure the fishing activity through rules and bodies which collaborate to an optimum management of the resource. Mexico's position on fishing activity is framed on aspects of fishing Mexican legislation, institutionalization and the industry intervention of RFMOS, considering that the importance of management and institutional incentives has increased.

Internally, the Mexican government has based their management policies and ${ }^{6}$ Comisión Intersecretarial de Cambio Climático. Informe de Avances del PECC 2009-2012. pp 50. ${ }^{7}$ General fishing law.-In Mexico it was created, authorized and implemented by the Chamber of Deputies, announced in the Official Gazette of the Fisheries Act in 1992; this law has had updates in 1999, 2001, 2004 and 2007 according to national and international changes. This law ensure the conservation, preservation and use the resources fishery to establish them for suitable promotion and administration. Everything is applicable according to the NDP see.

http://www.diputados.gob.mx/LeyesBiblio/abro/lpes/LPes abro.pdf 
regulations under the General Fishing Law (GFL 1992) ${ }^{7}$, Regulation of the Fisheries Law (1999) $)^{8}$, and the Fishing National Charter (CNP 2000) $)^{9}$. The Charter works as an instrument on cartographic and written version that has an informative purpose about the fishing resource susceptible of exploitation ${ }^{10}$.

In this way, it has been launched phases of control and regulation, promotion and development, social participation, political control and opening and deregulation. Legislation will still be the instrument which continues with the development plans of the country (Cruz-Ayala, and Igartúa-Calderón, 2006) [11].

Therefore, the legislation mentioned above, are three normative dimensions which lie on the management of the resource. These measures are executed to exercise control over the captures, using traditional methods as licenses and charges, the maximum quota of capture, fishing seasons, respect of closure or that one's of protection and special management, and alternative mechanisms that applies on incidental fishing and on individual fishing control ${ }^{11}$.

The strategy on the administration and the procedure of the management precise: the granting of fishing and aquaculture concessions and licenses, the verification of arts and the allowed equipment to carry out the activity. The resources availability is ruled according to evaluations and technique, economic and social studies, but mainly in the granting of quotas of capture to people with Mexican nationality or to legal persons constituted under Mexican laws.

However to put on practice the legislation, it is necessary the institutional view, the Secretariat of Environment and Natural Resources (SEMARNAT) holds the fishing management through policies, strategies and actions for sustainable use with benefits for the whole industry (Marín, (2007) [12]. Currently, it is up to Secretariat of Agriculture, Livestock, Rural Development, Fisheries and Food (SAGARPA) to follow up management, managing the use of seas on a

\footnotetext{
${ }^{8}$ Regulation of the fishing law. It was elaborated by the SEMARNAP to manage and regulate fisheries, this regulation works together with General Law of fisheries and PNC, this regulation is applied to optimize the natural resource to the management of commercial and civil society in their fishing activities see http://www.sagarpa.gob.mx/saladeprensa/Documents/RLGPAS3DEJULIO.pdf.

${ }^{9}$ The National Charter for fishing was founded in the year 2000, according to the changes given by the same process in the sector; the Charter has undergone updates in the years 2004, 2006, 2010, 2012 and 2014. The main changes were made on scientific, regulatory and operational bases, making to the activity safe in terms technical, economic and social. To ensure these terms, it was necessary the guide by letters national of fishing, plans of management fishing and aquaculture, standards official Mexican and technical opinions of these instruments, provide information detailed on the sector through technical and scientific works in order to take of decisions. This work covers the natural and coastal species both can be new as updated looking at areas of the Pacific and the Gulf of Mexico. All the evaluation and results about research scientific and technology is available in the book red called "sustainability and fishing responsible in Mexico" which contains data on assessments biological fishing, diagnostics of production, quality of the water, developments technological and projects to develop, these data are thrown of it application in different areas coastal and for different species. The updates and the reforms to the fishing sector goes chained to the Plan of National Development, of course regarding the international requirements. All this information can be consulted in INAPESCA:

http://www.inapesca.gob.mx/portal/component/content/article/17-publicaciones/74-carta-nacionalpesquera.

${ }^{10}$ DOF. SEMARNAP. Autorización CNP 2000.

${ }^{11}$ AIDA. Herramientas para la pesca sostenible y el manejo costero. pp 9, 23.
} 
profitable and sustainable way, for both the internal and external-markets, strengthening quality and responding to customer's requirements ${ }^{12}$.

On the international aspect, the Mexican government through the ministerial meeting of Cancun in 1992 proposed a code of responsible practice for fishing, and at the heart of the summit was decided to establish a normative document of international fishing activities; signed in $1995^{13}$.

Furthermore, Mexico attends the RFMOs ruling toward the Mexican fishing activity, making emphasis on the industry's disadvantages. These mismatches are found on fishing administration and on the geographical extent to manage. The capture is considerable situated in the northwest of the country, spear headed by sardine fishing, while the Gulf of Mexico presents a lower level of capture. Another aspect to highlight is the unbalance between the industrial and artisanal fleet.

Despite the regulatory and institutional reordering raised by Mexican government, international institutions suggest to the government the need to strengthen conservation and sustainable use of biodiversity. At the same time they recognized the effectiveness of the programs, rescue boats plans and licenses to ensure an improvement on the sustainable fishing management. However, the RFMOsen courage Mexico to reform the fishing sector to manage the ecosystem with more effectiveness and to obtain biological resources, which in turn will favor respectful environmental practices ${ }^{14}$.

According to international remarks from RFMOs, the Mexican government promotes programs related to each other, raised a holistic way, that is, integrated due to the need of coordinate diagnostic actions and technique operation of protected and economically important species(Espinoza-Tenorio y Espejel, 2012) [13].

The established programs are subjected to rules of operation with fishing and aquaculture components focused on food security, emphasizing; investment for equipment and infrastructure, the natural resources sustainable program and transversal projects ${ }^{15}$.

The programs derive from modernization projects of smaller vessels, incorporating modern and ecologic equipment that contribute to environmental care reducing fuel consumption. Within this program is the coverage for investment as a reconversion project from 2008-2011. Another variety of projects focuses on the decrease of fishing effort, mainly the removal of shrimp vessels to contribute on the use of sustainable resource.

The inspection and surveillance focus on fight against illegal fishing, among

\footnotetext{
${ }^{12}$ Gestión Pesquera en México. Coordinado por la Secretaría de Industria y Comercio de 1972, la Secretaría de Pesca de 1982, Secretaría de Medio Ambiente y Recursos Naturales y Pesca (SEMARNAP) en 1991 y la SAGARPA a partir del 2001. Asimismo, se fortalecen los asuntos pesqueros mediante las actividades de la Comisión Nacional de Acuicultura y Pesca (CONAPESCA), el Centro Informático para la Pesca (INFOPESCA) y el Instituto Nacional de Pesca (INAPESCA).

${ }^{13}$ FAO. Código de Conducta de la pesca Responsable 1995.

${ }^{14}$ OECD. Evaluaciones de la OCDE sobre el desempeño ambiental: México 2013. pp 17.

${ }^{15}$ SAGARPA. Programas sujetos a reglas de operación. Acuerdo anunciado en el DOF-2010.
} 
other media through satellite monitoring system. The project of systemic payment is applied in concessions and licenses on the frame of the productive reconversion of the Gulf of Mexico and the Caribbean. One last branch of the projects is focused on energetic resource such as: the use of marine diesel and the riverside gasoline, transport and trade of fishing resources and attention to natural disasters.

This modernization requires financial resources since they mean changes, improvement, provision, development and opening to address the climate change challenge. It is indispensable to count with economic resource in long term because as the modernization process is deepened, the financial requirement for infrastructure needs, equipment, machinery, operation supplies, human resource, services and technology will increase (Cebreros y Guarneros, 2006) [14].

Modernization will have to attach to social aspects, the environmental conservation and on the available financial resources. Considering that this strategy is developed in long term, is required to arrange investment both private and public. With all these, Mexico pretends to manage resource for international investment and financial services which require productive modernization and commercial opening.

Despite the disadvantages mentioned above, the Mexican fishing activity presented a rebound of 1.4\% annual between 2006-2011, especially because of the sardine species, which were the principal captured products, with $1.4 \mathrm{~m} / \mathrm{t}$ produced. SAGARPA, via CONAPESCA, applied a resource of approximately 3 million dollars for the programs described above and other resources in the presentation of projects that helped with fishing reordering. These programs are annually reviewed, but the sector still requires more reforms as; fiscal, infrastructure and innovation to achieve a major productivity (OMC, 2013) [15].

The Table 1 indicates the productivity and composition of the Mexican fishing activity.

In another perspective and taking into account that Mexico is member of the Inter-American Tropical Tuna Commission (IATTC) its regional participation is relevant through its tuna fleets, emphasizing the yellow fin tuna. This tuna is industrialized and is addressed to both the domestic and export markets. Furthermore, tuna is fished for two purposes; for fattening in sea corrals and for sale to international markets, which generates 50 million US dollars annually. Exports go the United States and Japan, which generates direct and indirect jobs

Table 1. Main appropriation lines of the Mexican fishing industry by 2010.

\begin{tabular}{cccc}
\hline Appropriation Line/Year & $\mathbf{2 0 0 3}$ & $\mathbf{2 0 1 0}$ & Observations \\
\hline Vessels & 239,539 & 217,176 & \\
Employment & 271,714 & 293,803 & \\
Capture & $1,279,060$ & $1,357,900$ & \\
$\begin{array}{c}\text { Financial resources provided by } \\
\text { the Mexican government. }\end{array}$ & $1,285,042$ & 931,965 & The first resource was in \\
\hline
\end{tabular}

Source: Compiled from data of the OECD document Review of fisheries: country statistics 2012. 
(MSNBC.com 2016a) [16]. Therefore, the IATTC includes 6,600 tons of bluefin tuna catch quotas (2017 and 2018) and the capture goes according to the stability of the industry. The measure is drastic, but seeks to maintain a control on mortality in addition to bluefin tuna continues to have problems of exploitation (MSNBC.com 2016b) [17]. According to the IATTC (2016) proposals for the protection of natural resources, specifically for tuna in the Pacific Ocean are on edge of capture either by individual ship and/or days of veda.

All the above mentioned have influenced the international trade since the products demand has increased strongly; 40 per cent of the total value and 33 per cent of the total volume of the produced fish entering international trade. The half of this volume is exported by developing countries (Delgado et al., 2003) [18], representing more than any other foodstuff export income (Thorpe et al., 2006) [19]. In this respect, fishing position tends to fluctuations and consequently becomes difficult in relation to commitments to international agreements with respect to the marketing of the product as well as partnerships between national and foreign fleets, considering that its activity can only be exercised in its EEZ so that trade would be affected.

According with these procedures, it can realize that climate change, international systems and governance are creating situations of vulnerability in the fisheries sector. These circumstances causes uncertainty in the fish markets facing an increasing demand due to increasing globalization, these commercial disorders will continue to be altering fisheries restructuring.

\section{Discussion}

The trading and restructuring fisheries in Mexico lies in three important aspects; the opinions and support by statistics and proposals generated by the RFMOS, the climatological phenomenon, and industrial waste. According to the former approach, the panoramic Mexican fishing notes that it serves and engages in international regulation, adapting them to its internal policies in regulatory, institutional aspects and application. Through them it fits and creates the implementation of programs and projects in favor of fishing. However, the fishing sector in Mexico, faces climate events that are intensified each time more derivative the greenhouse effect as well as the treatment of waste and modernization for the ravages of climate change. On the other hand, modernization provides through computer applications, processes administrative, customs, port infrastructure, fleet and transport in general, which can act on the exploitation of the resource, surveillance, transport and marketing. He is additionally subject to the provisions of capture, veda and banks which determines the RFOS. In summary the situation in Mexico affects the capitalization of programs and projects in the long term, requiring technologies, financial resources, treatment of waste water, meteorology and, finally, resources to be able to achieve the goal.

\section{Conclusions}

First at all, international agencies are cooperating in the fisheries restructuring; 
however, not all countries have the same infrastructure to follow up such a program. On the other hand, the environment is a decisive factor in the lack of resources, is something that cannot be controlled. Therefore, for developing countries, it is very difficult to confront these two processes since they require technology to respond requirements of international fisheries restructuring policies also to the environmental challenge.

Mexico faces these consequences, but the government is working on it; however there is another relevant sector that is being damaged because of the above, the fishing marketing sector. It is very hard to make political actions when necessary to cover market internal demand and give follow-up to its marketing with others countries.

Mexico is trying to create programs and projects that support all this kind of fisheries restructuring and marketing process but, they are in a long term.

\section{References}

[1] Keohane, R. and Nye, J. (1977) Power and Interdependence: World Politics in Transition. Little Brown, Boston.

[2] Katzenstein, P. (1976) International Relations and Domestic Structures: Foreign Economic Policies of Advanced Industrial States. International Organization, 30, 1-45. https://doi.org/10.1017/S0020818300003726

[3] Dahl, R. (1957) The Concept of Power. Systems Research and Behavioral Science, 2, 201-215. https://doi.org/10.1002/bs.3830020303

[4] Tucker, R. (1977) The Inequality of Nations. Basic Books, New York, 97.

[5] Holsti, O.R. (2006) Theories of International Relations. Making American Foreign Policy. Taylor and Francis Group, New York, 313-344.

[6] Sarukhán, J., et al. (2009) Síntesis: Conocimiento actual, evaluación y perspectivas de sustentabilidad, Comisión Nacional para el Conocimiento y Uso de la Biodiversidad. Gobierno Federal México, Capital Natural de México, México, 21-63.

[7] SEMARNAT (2007) "México ante el cambio climático" Instituto Nacional de Ecología. SEMARNAT, Secretaría de Medio Ambiente y Recursos Naturales. http://www2.inecc.gob.mx/publicaciones/gacetas/154/cclimatico.html

[8] OECD Review of Fisheries: Policies and Summary Statistics 2013 (2013) OECD Publishing, Paris, Cap. 26.

[9] Fernández, J. (2006) Características y problemas de la pesca en México. Pesca Acuacultura e Investigación en México, Comisión de Pesca, Centro de Estudios para el Desarrollo Rural Sustentable y la Soberanía Alimentaria CEDRSSA, Cámara de Diputados, 157-169.

[10] Daw, T., Adger, W.N., Brown, K. and Badjeck, M.C. (2009) El cambio climático y la pesca de captura: Repercusiones potenciales, adaptación y mitigación. In: Cochrane, K., De Young, C., Soto, D. and Bahati, T., Eds., Consecuencias del cambio climático para la pesca y la acuicultura: visión de conjunto del estado actual de los conocimientos científicos, FAO Documento Técnico de Pesca y Acuicultura No. 530, Roma, 119-168.

[11] Cruz-Ayala, M. and Igartúa-Calderón, L.E. (2006) La transformación de la legislación pesquera en México: Un acercamiento en el contexto político-económico (1925-1992). In: Guzmán Amaya, P. and Fuentes Castellanos, D.F., Coord., Pesca, acuacultura e investigación en México, Cámara de diputados, Comisión de pesca, 
CEDRESSA, México, 233-247.

[12] Marín, G. (2007) Pesca artesanal, comunidad y administración de recursos pesqueros. Experiencias en la costa de Michoacán, Gazeta de Antropología, Número 23, México, 23-20.

[13] Espinoza-Tenorio, A. and Espejel, I. (2012) Investigación sobre el manejo holístico de la pesca en México: Prioridades gubernamentales para el siglo XXI. Ciencia Pesquera, 20, 91-96.

[14] Cebreros, A. and Guarneros, J. (2006) Mecanismos financieros para la modernización de la pesca en México. In: Guzmán Amaya, P. and Fuentes Castellanos, D.F., Coord., Pesca, acuacultura e investigación en México, Cámara de diputados, Comisión de pesca, CEDRESSA, México, 135-143.

[15] OMC (2013) Examen de Políticas Comerciales. México, 14-138.

[16] Ensenada.Net (2016) Reeligen a Guillermo Compean al frente de la CIAT. órgano rector de la pesca atunera en el Pacífico, Noticia del 30 de Junio 2016 publicada por Elizabeth Vargas. http://www.ensenada.net/noticias/nota.php?id=45563

[17] Ensenada.Net (2016) Mantendrá CIAT cuotas de alea azul 2017 y 2018. 3,300 toneladas anuales para ranchos atuneros. Noticia del 03 de noviembre 2016 publicada por Karla Lorena Lamas. http://www.ensenada.net/noticias/nota.php?id=47025

[18] Delgado, C.L., Wada, N., Rosegrant, M.W., Meijer, S. and Ahmed, M. (2003) Fish to 2020: Supply and Demand in Changing Global Markets. World Fish Center, Penang.

[19] Thorpe, L.E., Gwynn, R.C., et al. (2006) Community Health and Nutrition Examination Surveys for Public Health Surveillance: The New York City Experience. Preventing Chronic Disease, 3, 1-8.

\section{Submit or recommend next manuscript to SCIRP and we will provide best service for you:}

Accepting pre-submission inquiries through Email, Facebook, LinkedIn, Twitter, etc. A wide selection of journals (inclusive of 9 subjects, more than 200 journals)

Providing 24-hour high-quality service

User-friendly online submission system

Fair and swift peer-review system

Efficient typesetting and proofreading procedure

Display of the result of downloads and visits, as well as the number of cited articles

Maximum dissemination of your research work

Submit your manuscript at: http://papersubmission.scirp.org/

Or contact jhrss@scirp.org 